\title{
The British RepubliC
}

1649-1660 


\title{
British History in Perspective General Editor: Jeremy Black
}

\author{
PUBLISHED TITLES
}

C. J. Bartlett British Foreign Policy in the Twentieth Century D. G. Boyce The Irish Question and British Politics 1868-1986 John Derry British Politics in the Age of Pitt $\mathbb{E}$ Liverpool

Ronald Hutton The British Republic 1649-1660

A. J. Pollard The Wars of the Roses

Robert Stewart Party and Politics, 1830-1852

FORTHCOMING TITLES

John Davis British Politics 1885-1931

Ann Hughes Causes of the English Civil War

Diarmaid MacCulloch Religion and Society 1547-1603

Michael Prestwich English Politics in the Thirteenth Century 


\title{
The BRITISH RepubliC 1649-1660
}

\author{
RONALD HUTTON \\ Lecturer in History \\ University of Bristol
}

Macmillan Education 
(C) Ronald Hutton 1990

Softcover reprint of the hardcover 1st edition 1990

All rights reserved. For information, write:

Scholarly and Reference Division,

St. Martin's Press, Inc., 175 Fifth Avenue,

New York, N.Y. 10010

First published in the United States of America in 1990

ISBN 978-0-333-40464-5 ISBN 978-1-349-20714-5 (eBook)

DOI 10.1007/978-1-349-20714-5

Library of Congress Cataloging-in-Publication Data

Hutton, Ronald.

The British Republic, 1649-1660 / Ronald Hutton.

p. $\mathrm{cm}$. - (British history in perspective)

Includes bibliographical references.

ISBN 978-0-312-04065-9

1. Great Britain-History-Commonwealth and Protectorate, 1649-1660. I. Title II. Series

DA425.H87 1990

$941.06^{\prime} 3$-dc20 


\section{Contents}

Preface

vii

$\begin{array}{ll}\text { Introduction } & 1\end{array}$

1 The Commonwealth 4

I The Central Regime 4

II The Localities 25

III British and European Affairs 44

2 The Protectorate 58

I Central Government $\quad 58$

II The Localities $\quad 78$

III British and European Affairs 98

3 From Protectorate to Monarchy 114

$\begin{array}{ll}\text { Conclusion } & 133\end{array}$

$\begin{array}{ll}\text { Notes } & 136\end{array}$

$\begin{array}{ll}\text { Bibliography } & 138\end{array}$

$\begin{array}{ll}\text { Index } & 145\end{array}$ 
For the Peerage of Redbridge, long ago:

Bramwell Tovey,

David Pearl

and

Christopher Freeman 


\section{Preface}

I agreed to write this book at the importunity of a friend, the commissioning editor, Jeremy Black. It was the first which I had ever attempted which synthesised the work of many colleagues with my own, so that for much of the time I was deploying the research of others. As such, I found the prospect of it rather forbidding: it was 'microwaved history', a heap of everything that seemed to be known upon the subject, heated through briefly with my own opinions and served up to the general reader. It is the hardest type of book with which to please professional colleagues, for what accords with their opinions will seem familiar and dull to them, and what does not will often seem irritating. My principal reason for agreeing to undertake it was that it represented an opportunity to provide students and the general public with the very latest picture of an important episode of history, in an accessible form and at an accessible price. In doing so, I was also closing a gap between the two periods in which most of my existing work has been concentrated, the 1640s and the years from 1658 to 1685 , and so completing a sequence of four books. Some of the ground was covered in my previous publications upon the Restoration and upon Charles II, and I have had to consider all of it during the years in which I ran a Special Subject upon the British Republic at Bristol University. It is customary for academics who chair such courses to comment upon the amount that they have learned from their students. I endorse this whole-heartedly, but 
I have gained a great deal from three of them in particular: Dominic Stuttaford, Bruce Yardley and Philip Norrey. The last became a research student at Bristol and produced a superb doctoral thesis upon the Restoration period before having to seek employment outside academe because of the current absence of opportunities within it. Wherever you are when this book is published, Phil, I hope that it gives you pleasure, for you could have written it better than $I$. 